\title{
Ecrhs
}

\section{Critical Thinking Development in the ESP Course for Engineering Students Based on Bloom's Taxonomy}

\author{
Sladjana Živković \\ College of Applied Technical Sciences, Niš, Serbia
}

\begin{abstract}
This paper discusses the importance of critical thinking within the ESP engineering course, and it shows possibilities for improving knowledge practice and skills, as well as for developing students' communicative abilities.

In this regard, and as for the needs of students, the author has applied Bloom's taxonomy of critical thinking in order to develop students' ability to think and apply it in a specific professional (engineering) context.

By the end of the course students should be able to provide an overview of the engineering field, apply knowledge to real life situations, ask questions and seek answers about a particular topic, develop engineering communication skills, communicate effectively, orally (speaking and listening) and in written form (writing and reading), work collaboratively with their classmates in order to maximize their own learning, and develop critical thinking skills (understand, analyze and interpret related information).
\end{abstract}

Key words: critical thinking, ESP course, engineering students, Bloom's taxonomy

\section{Introduction}

This study attempts to add to the knowledge how students learn engineering and how engineering courses can be used to develop students' critical thinking skills by assessing the effectiveness of Bloom's model for critical thinking on improving students' thinking abilities. As stated by Facione et al. (1990, 2007, 2011), the ability to think critically is considered as one of the primary tasks of education. So, regarding this, the study aims at presenting a critical thinking model within the ESP engineering classroom.

Entering today's global marketplace, employers look for graduates who are able to transfer their critical thinking abilities to the workplace (Tapper, 2004) and use a language "in the service of thinking and problem solving" (Cummins 1981).

As it is mentioned by Schafersman (1991), in order to be prepared for success in future, education must focus on developing the critical thinking skills of students. With these skills students will be prepared to cooperate successfully, think critically and analytically (Atkinson, 1997), communicate effectively and solve problems efficiently in the workplace.

\section{Design a course - articulate your learning objectives}

Taking a course into consideration, Brown (2004) argues that "the objectives of a curriculum are not limited to linguistic factors alone, but also include developing the art of critical thinking“. 
So, regarding learning objectives, it can be stated that critical thinking is one of the main objectives of the contemporary curricula. As pointed out by Facione and Facione $(2007,2011)$ it is "reflective decision-making and thoughtful problem-solving about what to believe and do". Further, "it is the intellectually disciplined process of actively and skillfully conceptualizing, applying, analyzing, synthesizing, and/or evaluating information gathered from, or generated by, observation, experience, reflection, reasoning, or communication, as a guide to belief and action" (Scriven and Paul 1996:63).

In this regard, and as for the needs of students, we have designed a critical thinking model in order to develop students' ability to think critically, and to apply it in a specific professional (engineering) context.

At the end of the course students should be able to provide an overview of the engineering field, apply knowledge to real life situations, ask questions and seek answers about a particular (engineering) topic, develop communication skills, communicate effectively, orally (speaking and listening) and in a written form (writing and reading) (Živković 2014, 2015a, 2015 b), work collaboratively with their classmates in order to maximize their own learning, develop critical thinking skills (understand, analyze and interpret related information).

The course is designed to show engineering students how important critical thinking skills are, and help them to improve their ability to think critically, and, thus, bring their thinking processes to light.

\section{A suggested model}

In addressing new concerns of education, we present a critical thinking model in the ESP engineering classroom which is based on improving student motivation and providing best practice strategies. The model provides students the opportunity to grow in their thinking and to transfer those thinking skills across contexts they should be able to evaluate.

Here, we have applied Bloom's taxonomy model which is divided into six levels each with keywords that exemplify the level and questions that focus on that same critical thinking level. Questions can help students to develop and enhance their thinking skills. Questions can be used to develop all levels of thinking within the cognitive domain. It encompasses effective communication and problem-solving abilities.

It results in "knowledge (the ability to remember previously learned material), comprehension (the ability to grasp the meaning of the facts and ideas), application (the ability to use learned material in new and concrete situations), analysis (the ability to break down a material into its component parts so that its organizational structure may be understood), synthesis (the ability to propose alternative solutions) and evaluation (the ability to present and defend opinions by making judgments about information) (Bloom, 1956).

\section{Classroom activities - Questioning}

For each of the critical thinking skills shown above it will be given a variety of questions. Questioning is learning-centered approach that challenges a person to develop their critical thinking skills and engage in analytic discussion which leads to independent learning and thinking. Effective questioning is one of the most useful strategies that teachers can use to promote critical thinking. Good questions are those that guide thinking and encourage students to interpret, analyze, synthesize, critique, and reflect.

According to Browne and Keeley (2007), encouraging the asking and answering of critical questions is one aspect of a larger part of educational practices called "active learning" that can identify a classroom as one where critical thinking is being encouraged. 


\section{icrhs}

4th International Conference On Research In HUMANITIES \& SOCIAL SCIENCES

Bearing in mind theoretical bases of course design, we now turn to the practical aspect that is resulted in communicating about specialized topics.

Engage the students in a discussion with the following questions.

Level 1: Knowledge

Learning objective verbs: arrange, define, describe, duplicate, identify, label, list, match, memorize, name, order, outline, recognize, relate, recall, repeat, reproduce, select, state

Activities

Some of the examples:

How do you define engineering?

Define a job of an engineer as a person trained and skilled in the design process

Make a list of engineering branches

Name job responsibilities

Level 2: Comprehension

Learning objective verbs: classify, convert, defend, discuss, distinguish, estimate, explain, express, extend, generalize, give example(s), identify, indicate, infer, locate, paraphrase, predict, recognize, rewrite, report, restate, review, select, summarize, translate

Activities

Here are a few examples:

Discuss an engineer as a practitioner

Explain knowledge of two-dimensional (2D) and three-dimensional (3D) forms used in engineering

Discuss how engineers use math and science

Report recent achievements in engineering

Identify a new approach in engineering design

Level 3: Application

Learning objective verbs: apply, change, choose, compute, demonstrate, discover, dramatize, employ, illustrate, interpret, manipulate, modify, operate, practice, predict, prepare, produce, relate schedule, show, sketch, solve, use write

Activities

Some of the examples are listed below:

Write about technological advances

Show the basic skills every engineer should have

Demonstrate some of the engineering projects

Level 4: Analysis

Learning objective verbs: analyze, appraise, breakdown, calculate, categorize, classify, compare, contrast, criticize, derive, diagram, differentiate, discriminate, distinguish, examine, experiment, identify, illustrate, infer, interpret, model, outline, point out, question, relate, select, separate, subdivide, test

Activities

Some common examples for this level are:

Analyze computational methods in engineering design

Analyze an experience for the engineering design process

Examine the needs to embed communication technologies in engineering 


\section{Ecrhs}

4th International Conference On Research In HUMANITIES \& SOCIAL SCIENCES

Illustrate engineering concepts and increase interest in engineering as a career

Level 5: Synthesis

Learning objective verbs: arrange, assemble, categorize, collect, combine, comply, compose, construct, create, design, develop, devise, explain, formulate, generate, plan, prepare, propose, rearrange, reconstruct, relate, reorganize, revise, rewrite, set up, summarize, synthesize, tell, write

Activities

Here are a few examples for this level:

Create your own logo for engineering

Create a computer engineering program

What would your advice be to future project teams

Level 6: Evaluation

Learning objective verbs: appraise, argue, assess, attach, choose, compare, conclude, contrast, defend, describe, discriminate, estimate, evaluate, explain, judge, justify, interpret, relate, predict, rate, select, summarize, support, value

Activities

Below are some examples for this level:

Determine your career goals

Conclude about engineers as practitioners

Argue about new ideas in engineering

\section{Discussion}

Within a new era, a radical shift will begin to occur in the world of education. In dealing with the transformation of the classroom, it can be displayed that the main goal of education is transforming class from theory with practice. Theory represents knowledge, while practice is the application of that knowledge (Breunig, 2005). Transformation begins in the classroom, and then moves towards self-transforming society. Transformation of both student and teacher is inherent throughout the theory of critical pedagogy (Freire, 1998; Giroux, 1985; Shor, 1996).

Within the transformation, we should not forget to say that education prepares students to be life-long learners, critical thinkers and problem solvers 'considering and pursuing novel ideas and leadership for action' (Fullan, 2013) in today's world.

Both students and the teacher face challenges in today's classroom. Taking into account a teacher's role as "a transformative intellectual" (Giroux, 1985), the challenge is to provide a relevant framework for students upon which they construct knowledge and become active participants in the learning process (Živković, 2014; Živković, 2015b). Taking this into account, it is clear that teachers should motivate students to improve their performances and become successful in their future job.

Teachers need to use cognitive strategies to address 21 st-century thinking, reasoning and problem-solving skills that transfer them into meaningful, relevant content-area instruction. This is a process "through which an individual becomes capable of taking what was learned in one situation and applying it to new situations (i.e., transfer). The product of deeper learning is transferable knowledge, including content knowledge in a domain and knowledge of how, why, and when to apply this knowledge to answer questions and solve problems" (Darling-Hammond, 2008). 
On the other hand, students should be given opportunities to be active in ways that will promote self-direction, creativity and the critical analysis of problems requiring a solution (Jonassen, 1994). Students should be trained to be critical readers who can "question, organize, interpret, synthesize, and digest what they read" (Paul and Elder, 2001; 2004).

According to Alvermann and Phelps (1998) "The curriculum must expand to include information and activities that explicitly support students in learning to think well. The emphasis is less on the mastery of information measured by a recall-based assessment and more on learning how to use one's mind well, to synthesize and analyze skillfully".

As a result, to prepare students to be competitive, they must be taught how to think critically, share ideas, analyze, make decisions in real-world situations.

"By internalizing the full range of critical thinking competencies, students will become more self-directed, self-disciplined, self-monitored thinkers. They will develop their ability to: - raise vital questions and problems (formulating them clearly and precisely),

- gather and assess relevant information (using abstract ideas to interpret it effectively and fairly),

- come to well-reasoned conclusions and solutions (testing them against relevant criteria and standards),

- think open-mindedly within alternative systems of thought (recognizing and assessing, as need be, their assumptions, implications, and practical consequences), and

- communicate effectively with others in figuring out solutions to complex problems“ (Elder, 2007).

From the point of view of Bonwell and Eison (2001), students should be engaged in more activities than just listening. They should be involved in higher-order thinking, such as interpretation, analysis, inference, evaluation, explanation and self-regulation, fostering students' learning performance, which means enable them to communicate and talk critically while expressing their views. According to Kalonji (2005), such activities require active involvement of students, engagement in high-level problem-solving skills, participating in team activities, and forging collaborative partnerships among multidisciplinary teams.

\section{Conclusion}

The aim of this paper was to develop an understanding of how new pedagogical models enable deeper learning outcomes and how it makes sense of our world by carefully examining our thinking and the thinking of others in order to clarify our understanding of the concept.

Here, the author discussed critical thinking development in the ESP classroom, as well as the effectiveness of Bloom's model on students' abilities to think critically about engineering and their knowledge of engineering course content. Athanassiou et al. (2003) focus on the use of Bloom's taxonomy as a framework for the student-centered management class and found out that this tool was useful to improve the students' skills.

Critical thinking should be taught in every discipline and at all education levels, but there is a growing concern over students' performance in STEM (science, technology, engineering, and math) fields. As Warren (2011) argues, the important goal of preparing students to be 'critically-reflexive citizens' in a world of constant competition is to apply critical thinking in the classroom.

By allowing students to think critically how to apply a concept to real-life situations, it deepens their understanding of a subject, and their ability to apply their prior knowledge on new situations. Various activities create such a learning environment that provides students with different opportunities, such as, sharing their knowledge, learning strategies and ideas, and engaging in communication with their classmates and teachers. 


\section{Eorhs}

\section{4th International Conference On Research In HUMANITIES \& SOCIAL SCIENCES}

Bearing all this in mind, traditional teaching-learning approach needs to be remodeled into modern education strategies and principles. In other words, the $21^{\text {st }}$ century learning environment needs students to be engaged in higher-order thinking skills - creativity, innovation, communication, collaboration, critical thinking and problem solving. Students should be allowed to freely express their views, and teachers should encourage them to think critically about what they are reading, seeing, and hearing critical thinking skills through modeling of effective practice.

\section{References}

Alvermann, P. D, \& S. Phelps (1998). Content reading and literacy, Boston: Allyn \& Bacon.

Athanassiou, N., McNett, J. M., \& Harvey, C. (2003), "Critical Thinking in the Management

Classroom: Bloom's Taxonomy as a Learning Tool”, Journal of Management Education, 27

(5); 533-555. https://doi.org/10.1177/1052562903252515

Atkinson, D. (1997). A Critical Approach to Critical Thinking. TESOL Quarterly, 31 (1), 71 94.

Bloom B.S. (1956). Taxonomy of Educational Objectives, Handbook I: The Cognitive Domain. New York: David McKay Co Inc.

Bonwell C, \& Eison J.A. (1991). Active learning: Creating excitement in the classroom, ASHEERIC Higher Education Report No. 1, Washington, DC: George Washington University.

Breunig M. (2005). Turning experiential education and critical pedagogy theory into praxis, The Journal of Experiential Education, 28(2), 106 -122.

Brown, H. D. (2004). Some practical thoughts about student-sensitive critical pedagogy. The Language Teacher, 28 (7), 23-27.

Browne, M. N., \& Keeley, S. M. (2007). Asking the right questions: A guide to critical thinking. Upper Saddle River, NJ: Prentice Hall.

Cummins, J. (1994). The role of primary language development in promoting educational success for language minority students. In C. F. Leyba (Ed.), Schooling and language-minority students: A theoretical framework, (2nd ed., pp. 3 - 46).

Darling-Hammond, H. (2008). Introduction: Teaching and learning for understanding. In L. Darling-Hammond, B. Barron, P. D. Pearson, A. H. Schoenfeld, E. K. Stage, T. D. Zimmerman, G. N. Cervetti, \& J. L. Tilson, Powerful learning: What we know about teaching for understanding (1-9). San Francisco, CA: John Wiley \& Sons.

Elder L. (2007). Why critical thinking? From http://www.criticalthinking.org/page.cfm?PageID=796\&CategoryID=103

Facione, P.A. (1990). "Critical thinking: a statement of expert consensus for purposes of educational assessment and instruction," The Delphi Report, Berkeley, Calif, USA: California Academic Press, pp. 1-19.

Facione, P.A. (2011). Think Critically, Pearson Education, N. J: Englewood Cliffs. 


\section{Eorhs}

\section{4th International Conference On Research In HUMANITIES \& SOCIAL SCIENCES}

Facione, P.A. \& Facione N.C. (2007). Talking critical thinking. Change, 39(2), 38-45. Retrieved July 15, 2007 from Academic SearchPremier.

Freire, P. (1998). Pedagogy of the Hearth. New York: The Continuum.

Fullan, M. (2013). Great to excellent: Launching the next stage of Ontario's education agenda. Retrieved from http://michaelfullan.ca/wpcontent/uploads/2016/06/13599974110.pdf

Giroux, H. (1985). Intellectual labor and pedagogical work: Rethinking the role of teacher as intellectual, Phenomenology + Pedagogy, 3(1), 20-32.

Jonassen, D.H. (1994). Thinking technology: Towards a Constructivist Design Model, Educational Technology, April, 34-37.

Kalonji, G. (2005). Capturing the imagination: High-priority reforms for engineering educators, National Academy of Engineering (Ed.), Educating the engineer of 2020: Adapting engineering education to the new century, Washington, DC: National Academies Press, 146-150.

Paul, R. \& Elder, L. (2000). The miniature guide to critical thinking: Concepts and tools. Dillon Beach, CA: Foundation for Critical Thinking--How to read a paragraph Dillon Beach, CA: Foundation for Critical Thinking.

Paul, R. \& Elder, L. (2001). Critical thinking and the art of close reading, Part III. Journal of Developmental Education, 28(1), 37.

Schafersman, S. D. (1991). "An Introduction to Critical Thinking," http://www.anintroductiontocriticalthinking.htm

Scriven, M. \& Paul, R. (1996). "Defining Critical Thinking," National Council for Excellence in Critical Thinking Instruction. Available http://www.criticalthinking.org/University/univlibrary/library.nclk

Shor, I. (1996). Empowering Education: Critical Teaching for Social Change, Chicago: University of Chicago Press.

Tapper, J. (2004). 'Student perceptions of how critical thinking is embedded in a degree program', Higher Education Research and Development, 23/2: 199-222.

Warren, J.T. (2011). Reflexive teaching: Toward critical autoethnographic practices of/in/on pedagogy, Cultural Studies of Critical Methodologies, 11 (2), 139-144.

Živković, (2014). Constructivism - An Emerging Trend in ESP Teaching and Learning, Nitra, Slovakia: Language, Literature and Culture in Education.

Živković, S. (2015a). Language Skills among Students in the Field of Engineering, European Journal of Language and Literature Studies, September-December, Volume 3, No. 1.

Živković, (2015b). A Constructivist Approach to the ESP Digital Classroom, Vistas of English for Specific Purposes, Cambridge: Cambridge Scholars Publishing. 